\title{
Penyuluhan Cuci Tangan Pada Anak-Anak Warga RT. 14 Kelurahan Jawa Samarinda Ulu
}

\author{
Siska Oktaviani, Hairunnisa \\ Universitas Widya Gama Mahakam Samarinda \\ email: siska@uwgm.ac.id
}

\begin{abstract}
This community service aims to provide knowledge and understanding to the children of RT. 14 Kelurahan Jawa, Samarinda Ulu on how to prevention of the spread of Covid-19 through the extension of hand-washing. The method carried out in the workshop through lectures with video media, demonstration and direct practice with 25 children of citizens of RT. 14 . Knowledge of children's early citizens of RT. 14 that the hand wash just wet the hands, but after counseling, there are 17 children who can practice the steps of proper hand washing according to WHO standards by using soap and running water. It is expected that after this extension there is a change of attitude in people, especially the children that they are fond of washing their hands properly, correctly and as often as possible. Hopefully this step into the road to block the spread of Covid-19.
\end{abstract}

Keywords: Counseling, Hand Washing, Children

\section{Abstrak}

Pengabdian masyarakat ini bertujuan memberikan pengetahuan dan pemahaman kepada anak-anak RT. 14 Kelurahan Jawa Samarinda Ulu mengenai cara pencegahan penyebaran Covid-19 melalui penyuluhan cuci tangan. Metode yang dilakukan pada penyuluhan ini melalui ceramah dengan media video, demonstrasi dan praktik langsung bersama 25 anak warga RT. 14. Pengetahuan awal anak-anak warga RT. 14 bahwa mencuci tangan hanya sekedar membasahi tangan, namun setelah penyuluhan, terdapat 17 anak yang dapat mempraktikkan langkah-langkah mencuci tangan yang benar sesuai standar WHO dengan menggunakan sabun dan air mengalir. Diharapkan setelah penyuluhan ini ada perubahan sikap pada masyarakat terutama anak-anak agar mereka gemar mencuci tangan dengan baik, benar dan sesering mungkin. Semoga langkah ini menjadi jalan guna menghadang penyebaran Covid-19.

Kata Kunci: Penyuluhan, Cuci Tangan, Anak-Anak

\section{PENDAHULUAN}

Pada Desember 2019, dunia dihebohkan dengan munculnya wabah Virus Corona atau yang juga dikenal dengan sebutan Covid-19, virus ini awalnya muncul di kota Wuhan negara China dan saat ini telah menyebar hampir di seluruh dunia. Berdasarkan data statistik dari (World Health Organization, 2020) per 5 Juni 2020 terdapat 6.516 .368 kasus terkonfirmasi positif Covid-19 dan 386.481 kasus meninggal dunia karena Covid-19 di seluruh dunia. Hal ini menjadi penanda bahwa penyebaran Covid-19 menjadi pandemi global.

Kini yang bisa kita lakukan adalah memutuskan rantai penyebaran Covid-19, dengan cara menjalankan protokol kesahatan, seperti menjaga jarak (physical distancing), menggunakan masker dan cuci tangan. Hal tersebut sudah dituangkan dalam (Depkes RI, 2014) bahwa terdapat 5 pilar sanitasi total berbasis masyarakat (STBM) yang di dalamnya terdapat perilaku cuci tangan dengan sabun. 
Perilaku mencuci tangan dengan sabun sebagai bentuk ikhtiar untuk mencegah penyebaran Covid-19 dapat dilakukan sejak dini kepada anak-anak. Karena menurut (Megawati, 2018) pada usia anak-anak rentan tertular penyakit dikarenakan sistem imun yang belum terbentuk dengan baik. Tangan sebagai salah satu anggota tubuh yang dapat menjadi media masuknya kuman penyakit ke dalam tubuh anak.

Kotoran, penyakit dan virus dapat juga melekat pada benda-benda lain, seperti mainan, uang, gagang pintu dan benda lainnya. Ketika benda-benda tadi dipegang anak kemudian tidak segera dibersihkan maka sangat mungkin anak dapat tertular penyakit termasuk virus (Kushartanti, 2012). Seperti yang telah kita ketahui, bahwa penyebaran Covid-19 salah satunya melalui tangan. Jika tangan telah terkontaminasi virus dan tangan tersebut menyentuh hidung, mata dan mulut, maka Covid-19 akan masuk ke paru-paru kemudian merusak sistem paru-paru yang dapat mengakibatkan sesak napas, dan jika sistem imun sedang rendah dapat menyebabkan gagal pernapasan. Maka mencuci tangan dengan sabun yang dilakukan secara benar, sangat penting agar kotoran, penyakit serta virus tidak masuk ke dalam tubuh anak.

Kurangnya kesadaran mencuci tangan dengan sabun masih banyak terjadi di kalangan masyarakat, termasuk anak-anak. Berdasarkan hasil pengamatan, pemahaman anak-anak mengenai pentingnya cuci tangan masih kurang. Hal tersebut dapat dilihat ketika mereka selesai bermain, masih ada saja anak yang tidak mencuci tangannya, kemudian saat mau makan, masih ada anak yang lupa mencuci tangannya terlebih dahulu.

Sehingga perlu usaha kongkrit dengan harapan dapat menjadi pembiasaan yang baik bagi anak-anak berupa penyuluhan cuci tangan dengan sabun yang benar. Diharapkan setelah penyuluhan ada perubahan sikap pada masyarakat terutama anak-anak agar mereka gemar mencuci tangan dengan baik, benar dan sesering mungkin. Semoga langkah ini menjadi jalan guna menghadang penyebaran Covid-19.

\section{METODE PENGABDIAN}

Kegiatan pengabdian kepada masyarakat berupa penyuluhan mencuci tangan ini terbagi menjadi tiga tahapan. Yang diawali dengan ceramah, pada tahapan ini diberikan informasi kepada anak-anak mengenai Covid-19, protokol kesehatan yang harus dilakukan, pengertian mencuci tangan, tujuan mencuci tangan, waktu yang tepat mencuci tangan dan langkah-langkah mencuci tangan yang benar. Materi ini disampaikan dengan media audio visual berupa video langkah-langkah mencuci tangan karena menurut (Asmara, 2015) penyampaian informasi melalui media audio visual lebih berhasil tersampaikan dibandingkan tidak menggunakan media audio visual. Dalam tahapan ini anak-anak juga diberi kesempatan bertanya apabila ada hal yang membingungkan mereka.

Tahapan selanjutnya adalah demonstrasi, pada tahapan ini anak-anak diminta untuk mendemonstasikan langkah-langkah mencuci tangan yang benar setelah mereka melihat video yang ditayangkan sebelumnya. Pemilihan metode demonstrasi digunakan dalam kegiatan penyuluhan ini karena metode demonstrasi memiliki banyak manfaat, salah satunya menurut Suparno (Putri, Tandililing, \& Mursyid, 2012) membuat suasana belajar lebih menarik, karena anak dapat merasakan belajar langsung tidak hanya mendengar saja. Ada pun langkahlangkah mencuci tangan yang benar (Ambarwati \& Prihastuti, 2019) antara lain: (1) siapkan alat dan bahan yang dibutuhkan; (2) basahi tangan dengan air; (3) tuang sabun secukupnya ke tangan; (4) ratakan sabun, gosok sampai berbusa selama 10-15 detik; (5) gosok punggung dan sela-sela jari tangan kiri dengan tangan 
dan sebaliknya; (6) gosok kedua telapak tangan dan sela-sela jari; (7) jari-jari sisi dalam kedua tangan saling mengunci; (8) gosok ibu jari kiri berputar dalam genggaman tangan dan lakukan sebaliknya; (9) gosok dengan memutar ujung jari-jari tangan kanan di telapak tangan kiri dan sebaliknya dan (10) bilas kedua tangan dengan air dan (11) keringkan tangan dengan lap tangan atau tisu.

Diakhir tahap demonstrasi, diberikan games bagi anak-anak yang dapat mencontohkan gerakan langkah-langkah mencuci tangan, anak yang dapat mencotohkan gerakan langkah-langkah mencuci tangan dengan benar, maka akan diberi reward. Menurut Purwanto (Puspitasari, 2015) reward adalah pemberian penghargaan kepada seseorang yang telah berhasil atas sesuatu yang telah dilakukan atau dihasilkan dan dalam kegiatan penyuluhan ini pemberian reward dilakukan untuk melihat antusias dan keseriusan anak-anak terhadap materi yang telah disampaikan.

Tahapan terakhir pada pengabdian kepada masyarakat adalah praktik. Pada tahap ini anak-anak dibawa ke halaman lokasi penyuluhan untuk mempraktikan langsung gerakan-gerakan mencuci tangan yang benar dengan alat dan bahan yang sudah disiapkan, seperti air mengalir, sabun dan lap tangan/tisu. Praktik ini dilakukan masing-masing anak.

\section{HASIL DAN PEMBAHASAN}

Kegiatan penyuluhan cuci tangan ini dilaksanakan pada hari Minggu, 7 Juni 2020 dari pukul $09.00-11.00$ Wita di kediaman Ibu Tuti yang merupakan salah satu warga di RT. 14 Kelurahan Jawa Samarinda. Penyuluhan yang dihadiri 25 anak warga RT. 14 ini berjalan dengan baik dan lancar, dalam pelaksanaan penyuluhan juga menjalankan protokol kesehatan seperti menggunakan masker.

Kegiatan diawali dengan memberi informasi kepada anak-anak mengenai Covid-19, protokol kesehatan yang harus dilakukan, pengertian mencuci tangan, tujuan mencuci tangan, waktu yang tepat mencuci tangan dan langkah-langkah mencuci tangan yang benar (Gambar 1). Anak-anak juga diberi pertanyaan secara lisan mengenai langkah-langkah cuci tangan, dan ternyata sebagian besar anakanak di RT. 14 belum mengetahui langkahlangkah mencuci tangan yang benar sebagaimana aturan Badan Kesehatan Dunia (WHO)

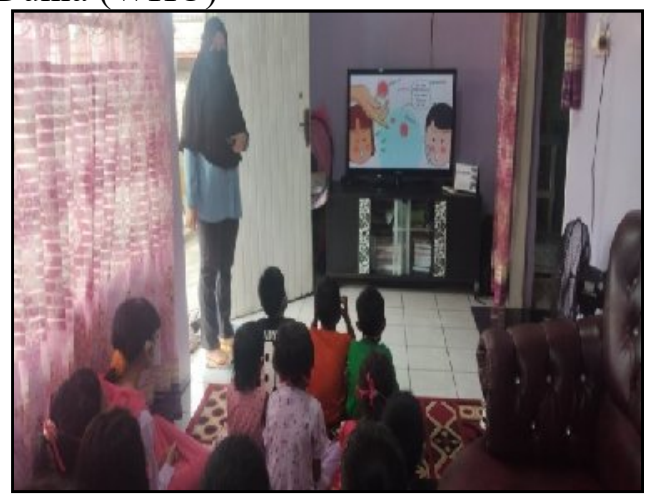

Gambar 1. Penyampaian Materi

Selain memberi informasi secara lisan kepada anak-anak, tim penyuluhan juga memberi informasi melalui video. Terlihat anak-anak antusias menonton video langkah-langkah mencuci tangan. Anakanak pun sembari mengikuti gerakan yang ditayangkan (Gambar 2). Sesi tanya jawab juga diberikan kepada anak-anak apabila ada hal yang masih membingungkan mereka.

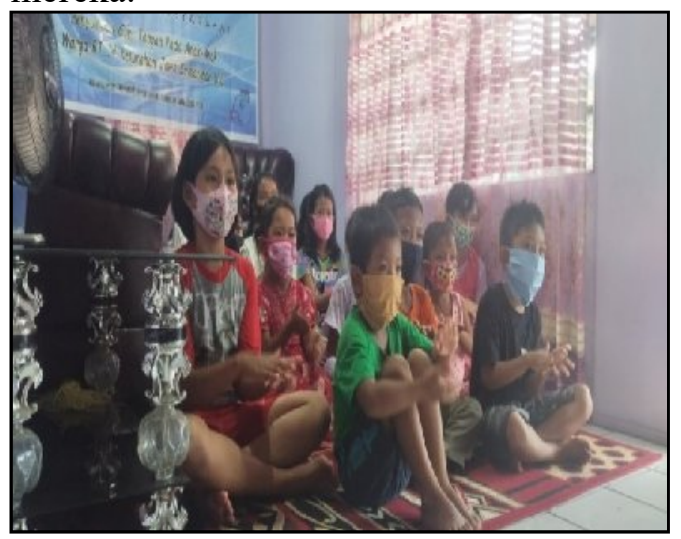

Gambar 2. Mengikuti Gerakan Mencuci Tangan

Kegiatan penyuluhan dilanjutkan dengan kegiatan demonstrasi, perwakilan dari anak-anak peserta penyuluhan diminta 
untuk mendemostrasikan gerakan langkahlangkah mencuci tangan yang sudah mereka pelajari sebelumnya (Gambar 3)

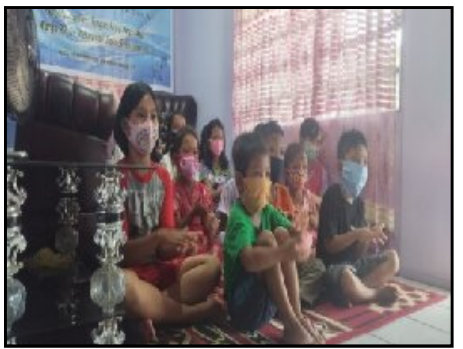

Gambar 3. Mendemonstrasikan Gerakan Mencuci Tangan

Anak-anak yang dapat mendemonstrasikan langkah-langkah cuci tangan dengan benar diberi hadiah sebagai bentuk apresiasi atas keberanian dan antusias mereka mengikuti penyuluhan.

Kegiatan penyuluhan kemudian dilanjutkan dengan praktik. Anak-anak diminta langsung mencuci tangan mereka pada tempat cuci tangan yang sudah disediakan. Pada kegiatan ini terlihat anakanak sudah dapat memahami langkahlangkah mencuci tangan yang benar, karena menurut Chusnul (Setyawati, 2018) persentase pengalaman belajar seseorang adalah $10 \%$ dari apa yang dia baca; $20 \%$ dari apa yang dia dengar; $30 \%$ dari apa yang dia lihat; $50 \%$ dari apa yang dia lihat dan dengar; $70 \%$ dari apa yang dia katakan dan $90 \%$ dari apa yang dia katakan dan lakukan.

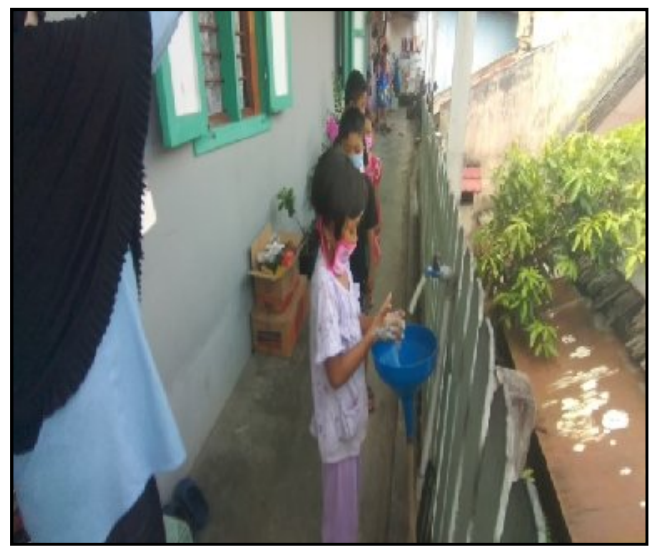

Gambar 4. Mempraktikkan Cuci Tangan yang Benar
Setelah dilakukan penyuluhan dengan media video langkah-langkah cuci tangan sesuai standar WHO serta praktik langsung dengan air mengalir (Gambar 4), anakanak warga RT. 14 menjadi paham pentingnya cuci tangan pada masa pandemi seperti ini, mereka pun juga memahami tata cara yang benar saat mencuci tangan, hal ini menjadi ilmu baru bagi mereka. Menurut (Kemenkes RI, 2011) anak-anak usia dini, baik jenjang TK maupun SD/MI merupakan sasaran utama dalam implementasi hidup sehat. Hal ini karena anak-anak pada usia dini masih dalam masa bereksplorasi, berkumpul dan bermain, ini yang membuat tak jarang mereka abai dalam menjaga kebersihan, salah satunya mencuci tangan. Sehingga tak jarang mereka rentan terhadap penyakit. Untuk itu harus terus digalakkan pembiasaan hidup sehat pada anak usia dini.

\section{SIMPULAN}

Pelaksanaan penyuluhan mencuci tangan yang dilakukan melalui ceramah dengan media video, demonstrasi dan praktik langsung berjalan dengan lancar serta membuat anak-anak di RT. 14 Kelurahan Jawa Samarinda Ulu menjadi paham pentingnya cuci tangan sebagai bentuk pencegahan penularan Covid-19, mereka pun juga memahami tata cara yang benar saat mencuci tangan, hal tersebut dapat dilihat dari 25 anak yang mengikuti penyuluhan terdapat 17 anak yang dapat mempraktikkan langkah-langkah mencuci tangan dengan benar sesuai dengan standar WHO. Menjaga kebersihan dan kesehatan dengan cara mencuci tangan dengan sabun dan air mengalir harusnya menjadi tanggung jawab bersama, antara orang tua, sekolah dan masyarakat sehingga mencuci tangan ini dapat menjadi kebiasaan yang baik bagi anak-anak.

\section{UCAPAN TERIMA KASIH}

Penulis mengucapkan terima kasih kepada lembaga penelitian dan pengabdian 
masyarakat (LPPM) Universitas Widya Gama Mahakam Samarinda yang telah memberikan bantuan dana untuk kegiatan pengabdian kepada masyarakat ini.

\section{DAFTAR PUSTAKA}

[1] Ambarwati, E. R., \& Prihastuti, P. (2019). Gerakan Masyarakat Hidup Sehat (Germas) Mencuci Tangan Menggunakan Sabun Dan Air Mengalir Sebagai Upaya Untuk Menerapkan Perilaku Hidup Bersih Dan Sehat (Phbs) Sejak Dini. Celebes Abdimas: Jurnal Pengabdian Kepada Masyarakat, 1(1), 45-52.

[2] Asmara, A. P. (2015). Pengembangan media pembelajaran berbasis audio visual tentang pembuatan koloid. Jurnal Ilmiah Didaktika: Media Ilmiah Pendidikan Dan Pengajaran, 15(2), 156-178.

[3] Depkes RI. (2014). Peraturan Menteri Kesehatan Republik Indonesia No. 3 Tahun 2014 Tentang Sanitasi Total Berbassi Masyarakat. Retrieved from http://hukor.kemkes.go.id/uploads/p roduk_hukum/PMK No. 3 ttg Sanitasi Total Berbasis Masyarakat.pdf

[4] 'Kemenkes RI. (2011). Pedoman Pembinaan Perilaku Hidup Bersih dan Sehat (PHBS). Jakarta: Kementerian Kesehatan Republik Indonesia.

[5] Kushartanti, R. (2012). Beberapa faktor yang mempengaruhi perilaku cuci tangan pakai sabun (CTPS)(studi di Sekolah Dasar Negeri Brebes 3). Program Pascasarjana Undip. Retrieved from http://eprints.undip.ac.id/42527/1/B ab_I-IV.pdf

[6] Megawati, A. (2018). Peningkatan Kualitas Kesehatan Anak Dengan Penerapan Cara Mencuci Tangan Yang Benar Dan Pengenalan Tentang Obat Kepada Anak Usia Dini. Jurnal Pengabdian Kesehatan,
1(1). Retrieved from http://jpk.jurnal.stikescendekiautam akudus.ac.id/index.php/jpk/article/vi ew/6/6

[7] Puspitasari, R. (2015). Pengaruh pemberian hadiah (reward) terhadap kemandirian belajar anak di TK Tunas Muda Karas Kabupaten Magetan TA 2015/2016. In Seminar Nasional Ilmu Pendidikan UNS 2015. Sebelas Maret University.

[8] Putri, N. R., Tandililing, E., \& Mursyid, S. (2012). Penerapan metode demonstrasi untuk meremediasi miskonsepsi siswa pada materi hukum Newton di SMP. Tanjungpura University.

[9] Setyawati, E. (2018). Upaya Peningkatan Hasil Belajar IPA Melalui Model Pembelajaran Discovery Learning Pada Peserta Didik. Ilmu Pendidikan: Jurnal Kajian Teori Dan Praktik Kependidikan, 3(1), 50-59.

[10] World Health Organization. (2020). WHO Coronavirus Disease (COVID-19). Retrieved from https://covid19. who.int/?gclid=EAI aIQobChMI4taCysi76QIVDyQrCh 0jIgdKEAAYASAAEgJUR_D_Bw $\mathrm{E}$ 